\title{
BIOMASS AND ENERGY PRODUCTION AT SHORT ROTATION Eucalyptus CLONAL PLANTATIONS DEPLOYED IN RIO GRANDE DO NORTE ${ }^{1}$
}

\author{
Maraísa Costa Ferreira ${ }^{2}$, Rosimeire Cavalcante dos Santos ${ }^{2}$, Renato Vinícius Oliveira Castro ${ }^{3 *}$, Angélica \\ de Cássia Oliveira Carneiro ${ }^{4}$, Gualter Guenther Costa da Silva ${ }^{2}$, Ana Flávia Neves Mendes Castro ${ }^{3}$, Sarah \\ Esther de Lima Costa ${ }^{2}$ and Alexandre Santos Pimenta ${ }^{2}$

\begin{abstract}
${ }^{1}$ Received on 08.08.2014 accepted for publication on 30.11.2016.
${ }^{2}$ Universidade Federal do Rio Grande do Norte, Unidade Acadêmica Especializada em Ciências Agraria, Macaíba, RN, Brasil .E-mail:<marabio_rn@hotmail.com>,<meire_caico@yahoo.com.br>,<gualtergcs@yahoo.com.br $>,<$ sarahcostaa@yahoo.com.br $>$ and<aspimenta@ufrnet.br>.

${ }^{3}$ Universidade Federal de São João Del-Rei, Departamento de Ciências Agrárias, Sete Lagoas, MG, Brasil .E-mail: <castrorvo@ymail.com> and $<$ mendesafn@hotmail.com>
\end{abstract} \\ ${ }^{4}$ Universidade Federal de Viçosa, Departamento de Engenharia Florestal, Viçosa, MG, Brasil . E-mail: <cassiacarneiro@ufv.br>. \\ *Corresponding author.
}

\begin{abstract}
This study aimed to estimate the biomass and energy of a clonal planting short rotation experiment with hybrids of Eucalyptus urophylla ST Blake x Eucalyptus grandis (Hill) Maiden, deployed in $3 \mathrm{~m} \times 3$ $\mathrm{m}$ spacing, at the Academic Unit Specialized in Agricultural Sciences, Macaíba/RN. The analysis were performed at the Laboratory Panels and Wood Energy, Federal University of Viçosa, in which the following ratings on wood three cultivars (GG100; AEC0144 and AEC0224) were performed: determination of basic density, high calorific power, chemical analysis, thermogravimetric analysis and subsequent calculations for estimating the mass production and energy were performed. The base $(10 \mathrm{~cm}$ from the ground $)$, the third and two thirds of commercial tree height: composed for analysis, taken from three points along the stem samples were used. The design of the experiment was a completely randomized. Data were subjected to analysis of variance and the means were compared by Tukey test $(\alpha=0.05)$. The clone who excelled in the first year of planting was the GG100 with $11,805 \mathrm{~kW}$.h.ha ${ }^{-1}$ of energy productivity, followed by clone AEC 0224 (6,755 kW.h.ha$\left.{ }^{1}\right)$ and AEC0144 (4,405 kW.h.ha $\left.{ }^{-1}\right)$. The performance of this clone was due to mainly the higher volumetric growth. The wood quality among clones showed little difference. It should stimulate the deployments of species of short rotation in the state of RN to supply the elevated energy demand of forest biomass in the region.
\end{abstract}

Keywords: Energy productivity, wood parameters, Eucalyptus clones.

\section{PRODUÇÃO DE BIOMASSA E ENERGIA EM PLANTIO CLONAL DE Eucalyptus DE CURTA ROTAÇÃO IMPLANTADO NO RIO GRANDE DO NORTE}

RESUMO - O presente estudo objetivou estimar a produção de biomassa e energia de um plantio clonal experimental de curta rotação, com híbridos de Eucalyptus urophylla S. T. Blake x Eucalyptus grandis (Hill) Maiden, implantados em espaçamento $3 \times 3$ m, na Unidade Acadêmica Especializada em Ciências Agrárias, Macaíba/RN. As análises foram realizadas no Laboratório de Painéis e Energia da Madeira da Universidade Federal de Viçosa, no qual foram realizadas as seguintes avaliações na madeira de três materiais genéticos (GG100; AEC0144 e AEC0224): determinação da densidade básica, poder calorífico superior, análise química, análise termogravimétrica e posteriormente foram realizados cálculos para a estimativa da produção de massa e energia. Foram utilizadas amostras compostas para as análises, retiradas de três pontos ao longo do fuste: da base (10 cm do solo), a 1/3 e a 2/3 da altura comercial da árvore. O experimento foi instalado segundo delineamento inteiramente casualizado. Os dados obtidos foram submetidos à análise de variância, sendo as médias comparadas pelo teste de Tukey $(\alpha=0,05)$. O clone que se sobressaiu, no primeiro ano de plantio foi o GG100, com $11.805 \mathrm{~kW} . h . h a^{-1}$ de produtividade energética, seguido do clone AEC0224 (6.755 
$k W \cdot h . h a^{-1}$ ) e AEC0144 (4.405 kW.h.ha-1). O melhor desempenho energético do clone GG100 foi devido, principalmente, ao maior crescimento volumétrico. A qualidade da madeira entre os clones apresentou pouca diferença. Devem-se estimular implantações de espécies de curta rotação no estado do RN para suprimento da alta demanda energética de biomassa florestal da região.

Palavras chaves: Produtividade energética, parâmetros de qualidade da madeira, clones de Eucalyptus.

\section{INTRODUCTION}

The search for fast-growing and high-yielding forests has increased due to the need for technological development on a more sustainable basis, as well as a reduction in the use of fossil fuels. Biomass, an important source of renewable energy, came to be valued as an energy input during the 1970s. During the 1990s, it gained prominence in the world energy scenario, mainly due to the technological development and environmental issues of great discussion worldwide (Nogueira et al., 2000).

When the goal is energy production, Eucalyptus is one of the most used forest biomass. This is due to the wide ecological distribution and the large number of species of this genus that facilitates its introduction in regions with different edaphoclimatic conditions. Besides, it has renewable energy potential and is an alternative that can help to decrease the use of fossil fuels (Paludo et al., 2013).

The production of Eucalyptus has great economic, environmental and social importance, and its wood has served the energy demand mainly in the form of firewood and charcoal. Eucalyptus cultivation promotes benefits to the country through the use of its products and services, besides being a source of important raw material, which is available as an option to the extraction of native species. It is, therefore, a sustainable culture with an important role in preservation activities (Mora and Garcia, 2000).

Although the Eucalyptus crop is widespread in Brazil, little is known about the performance of this genus in different regions of the Brazilian Northeast, especially in the State of Rio Grande do Norte (RN). However, wood consumption in this state is significant, with approximately 13 million tons per year, and most of this wood is obtained from native wood (Pareyn et al., 2013).

Thus, it is necessary to develop studies on the performance of Eucalyptus cultivation in Rio Grande do Norte, to provide basic information that serve as a reference for the development of plantations of this genus in the State. In addition, it is important to evaluate the energy potential of the clones, so that it is possible to infer which genetic material best adapted the environmental conditions imposed by the region and provides quality wood for energy production.

Hence, the aim of this study was to estimate the mass and energy production in a clonal Eucalyptus experimental planting, a year old, established in the state of Rio Grande do Norte.

\section{MATERIALAND METHODS}

To carry out this work were used three genetic material, at 12 months of age, Eucalyptus urophylla ST Blake x Eucalyptus grandis (Hill) Maiden hybrid. Experimental planting was developed at the Specialized Academic Unit in Agricultural Sciences, Federal University of Rio Grande do Norte, in the municipality of Macaíba-RN. This region has climatic characteristics that vary between types A'and BSh', according to Köppen classification, with high temperatures throughout the year and the rainy season in autumn and winter. The average annual rainfall is approximately $1,227 \mathrm{~mm}$ and has an average annual temperature of $26^{\circ} \mathrm{C}$ (Cestaro and Smith, 2004).

The experimental planting comprises an area of 6.6 ha, implanted in spacing of $3 \mathrm{~m} \times 3 \mathrm{~m}$. The trees were distributed in six plots, two plots for each clone. Two permanent plots were installed in each block, systematically, with dimensions of $324 \mathrm{~m}^{2}(18 \mathrm{~m} \times 18 \mathrm{~m})$. To perform the chemical and physical analysis on wood, two trees of medium height were selected, per plot, totaling eight trees per clone. The selection of the individuals performed excluded those that visually presented defects. All individuals within the plots had their DBH $(\mathrm{cm})$ and total height $(\mathrm{m})$ measured at one year of age.

From the felled trees, three discs were extracted: one at the base $(10 \mathrm{~cm}$ from the ground), another at $1 / 3$ and another at $2 / 3$ of the commercial height of the tree. The disks were sent to the Wood Panel and Energy Laboratory (LAPEM) of the Federal University of Viçosa, to carry out the chemical, physical and energy analysis of the wood of the different genetic materials.

Revista Árvore. 2017;41(5):e410504 
For the determination of the basic density of the wood, two opposing wedges were extracted from each disk and the remaining material was directed to determine the structural and immediate chemical composition, thermogravimetric decomposition and the higher calorific value. The analysis was performed in composite sampling.

The basic wood density was determined according to the water immersion method described by Vital (1984). The values of the basic density were obtained from an arithmetic mean of the densities of the respective wedges and discs.

The calorific value was determined in an adiabatic calorimeter pump according to ABNT NBR 8633 (ABNT, 1984).

The determination of the extractive content of the wood was determined in duplicates, according to the TAPPI 264 om-88 (TAPPI, 1998) standard, changing the ethanol / benzene mixture, by ethanol / toluene ratio $1: 2$.

The insoluble lignin contents were determined in duplicate by the modified Klason method according to the procedure proposed by Gomide and Demuner (1986), derived from the standard TAPPI T $222 \mathrm{om}-88$. The soluble lignin was determined by spectrometry, according to Goldschimid (1971), from the dilution of the samples from the procedure to obtain the insoluble lignin. Then the total lignin content was determined by summing the values found for insoluble and soluble lignin. With the sum of the contents of extractives and total lignin decreased by 100 the holocelluloses content was obtained.

The immediate chemical analysis of the wood (contents of volatile materials, ashes and fixed carbon) was determined following ABNT NBR 8112 (ABNT, 1986).

For the thermogravimetric analysis (TGA) of the wood was used the TGA-1000 Thermogravimetric Analyzer, Navas Instruments. From the thermograms, the mass loss was calculated in the following temperature ranges: $100^{\circ}-200^{\circ} \mathrm{C} ; 200^{\circ}-300^{\circ} \mathrm{C}, 300^{\circ}-400^{\circ} \mathrm{C} ; 400^{\circ}-500^{\circ} \mathrm{C}$ and the sum to the temperature of $500^{\circ} \mathrm{C}$.

The dry mass of wood without bark per hectare/ year was obtained by multiplying the average annual increment $\left(\mathrm{m}^{3} \cdot \mathrm{ha}^{-1}\right.$.year-) of debarked wood for wood density $\left(\mathrm{kg} \mathrm{m}^{-3}\right)$. Lignin masses, expressed in tonne, were determined by multiplying the dry mass of wood by the percentage of total lignin.
The dry mass of wood of each clone was obtained from the specific gravity $\left(\mathrm{kg} \cdot \mathrm{m}^{-3}\right)$ found in $1 \mathrm{~m}^{3}$ of wood. To calculate the energy per hectare, expressed in Kcal was multiplied the dry mass of wood (Kg.ha$\left.{ }^{1}\right)$ by its gross calorific value of each clone. For energy conversion kcal.ha ${ }^{1}$ to $\mathrm{kW} . \mathrm{h} . \mathrm{ha}^{-1}$, the values were divided in Kcal per 860, as Santos (2010).

The data were submitted to the Lilliefors and Cochran tests to test the normality and homogeneity of the variances, respectively. Then, analysis of variance by the F test, the means being compared by the Tukey test. For the variables Superior Calorific Power $\left(\mathrm{Kcal} . \mathrm{Kg}^{-1)}\right.$ and Basic Density Wood $\left(\mathrm{kg} \mathrm{m}^{-3}\right)$, we used the nonparametric Kruskal-Wallis test for those that did not show homogeneity of variances. The significance level of $5 \%$ was always considered. Statistical analysis was performed with the aid of the STATISTICA 7.0 program.

\section{RESULTS}

Table 1 shows the results obtained for basic wood density, high heat value, soluble lignin content, insoluble and total extractives content and holocellose content. It is observed that for the basic density was no significant difference between the different genetic materials and GG100 clone had the highest basic density value of wood $\left(371 \mathrm{~kg} \mathrm{~m}^{-3)}\right.$ and higher above the AEC0144 clones (339 $\left.\mathrm{kg} \mathrm{m}^{-3}\right)$ and AEC0224 (343 kg. $\left.\mathrm{m}^{-3}\right)$.

In Table 1, it is observed that there was no significant difference to the higher calorific value of the wood and the observed values were: GG100 - 4650 Kcal. Kg ${ }^{-1}$; AEC0144 - 4635Kcal.Kg ${ }^{-1}$; AEC0224 $4596 \mathrm{Kcal}_{\mathrm{K}} \mathrm{Kg}^{-1}$. It was observed that for insoluble lignin and extractive content there was a significant difference between the clones, whereas for soluble lignin, total lignin and holocelluloses there was no significant difference between the genetic materials.

In Table 2 the average values of chemical analysis on the basis of the clones are shown. The highest contents of volatile materials were observed for clones GG100 and AEC0144, both with 84\%, and the lowest average value was found for clone AEC 0224 with $83 \%$. No significant statistical difference was observed among the clones for this variable. The fixed carbon content also did not differ statistically between the different genetic materials evaluated. The lowest gray content was found for clone GG100 (0.84\%), differing statistically from the others that presented $1.16 \%$ and $1.17 \%$ in 
Table 1 - Basic density average values, gross calorific value, lignin, extractives and holoceluloses of hybrid clones of Eucalyptus urophylla ST Blake x Eucalyptus grandis (Hill) Maiden, at one year old.

Tabela 1 - Valores médios da Densidade Básica da Madeira do Poder Calorifico Superior, Teor de Lignina, Extrativos e Holocelulose da madeira de clones híbridos de Eucalyptus urophylla S.T. Blake x Eucalyptus grandis (Hill) Maiden, com um ano de idade.

\begin{tabular}{cccccccc}
\hline Genetic material & DBM & PCS * & Li & LS & LT & TET & HOLO \\
\cline { 2 - 8 } & Kg.m ${ }^{-3}$ & Kcal.Kg ${ }^{-1}$ & & & $(\%)$ & & \\
\hline GG100 & $371 \mathrm{a}$ & $4,650 \mathrm{a}$ & $27.24 \mathrm{a}$ & $3.66 \mathrm{a}$ & $30.9 \mathrm{a}$ & $2.73 \mathrm{~b}$ & $66.37 \mathrm{a}$ \\
AEC0144 & $339 \mathrm{~b}$ & $4.635 \mathrm{a}$ & $23.03 \mathrm{~b}$ & $5,4 \mathrm{a}$ & $28.43 \mathrm{a}$ & $3.14 \mathrm{a}$ & $68.43 \mathrm{a}$ \\
AEC0224 & $343 \mathrm{~b}$ & $4.596 \mathrm{a}$ & $27.42 \mathrm{a}$ & $4.05 \mathrm{to}$ & $31.47 \mathrm{a}$ & $2.65 \mathrm{~b}$ & $65.88 \mathrm{a}$ \\
\hline
\end{tabular}

In which: $\mathrm{DBM}=$ basic density of wood; PCS = higher calorific value; LI = insoluble lignin; LS = soluble lignin; LT = total lignin; TET $=$ extractive content; HOLO $=$ holocelluloses.

* Means followed by same letters do not differ from each other $(\alpha=0.05)$ by non-parametric Kruskall-Wallis test. Means followed by the same letters in the columns, do not differ from each other $(\alpha=0.05)$ by the Tukey test.

Table 2 - Mean values of fixed carbon, volatiles and ash in wood of hybrid clones of Eucalyptus urophylla ST Blake $\mathrm{x}$ Eucalyptus grandis (Hill) Maiden at one year of age.

Tabela 2 - Valores médios de carbono fixo, materiais voláteis e cinzas na madeira dos clones híbridos de Eucalyptus urophylla S.T. Blake x Eucalyptus grandis (Hill) Maiden, com um ano de idade.

\begin{tabular}{cccc}
\hline Genetic material & CF & MV & CZ \\
\cline { 2 - 4 } & \multicolumn{3}{c}{$(\%)$} \\
\hline GG100 & $14.97 \mathrm{~A}$ & $84 \mathrm{TO}$ & $0.84 \mathrm{~B}$ \\
AEC0144 & $14.33 \mathrm{~A}$ & $84 \mathrm{TO}$ & $1,16 \mathrm{~A}$ \\
AEC0224 & $15.8 \mathrm{~A}$ & $83 \mathrm{~A}$ & $1.17 \mathrm{~A}$ \\
\hline
\end{tabular}

Where: $\mathrm{CF}=$ fixed carbon, $\mathrm{MV}=$ volatile materials, $\mathrm{CZ}=\mathrm{ash}$. * Means followed by the same letters do not differ in the same column, $5 \%$ significance by Tukey test.

clones AEC0144 and AEC0224, respectively.

Table 3 shows the mass loss values as a function of the temperature ranges. The TGA analysis show the percentage of mass losses as a function of temperature, evidencing the thermal degradation profiles of the wood of the different genetic materials evaluated. When the degradation of the sample occurs, it is observed a dip of the curves around $260^{\circ} \mathrm{C}$ to $360^{\circ} \mathrm{C}$ for the three clones, with small differences in the temperatures referring to the maximum peaks of degradation of the wood. The thermogravimetric behavior of the analyzed clones show similarities in most of them overlapping in some points, therefore, not occurring significant differences between them. The thermal decomposition profiles of the wood of the different clones presented small temperature distinctions in the region of maximum degradation. It can be seen from the data shown in Table 3 that clones GG100 and AEC0144 showed the lowest total mass loss (74\% on average) in the temperature range of $100^{\circ}$ to $500^{\circ} \mathrm{C}$, which refers to the thermal stability of the wood of these materials when compared to the clone AEC0224 (76\%).

In the temperature range of $100^{\circ}$ to $200^{\circ} \mathrm{C}$ the mass loss was minimal, on average $1 \%$ for the three clones. The greatest mass loss observed between the temperature ranges from $300^{\circ}$ to $400^{\circ} \mathrm{C}$ was for clone AEC0144, which presented an average value of $47 \%$, which may be related to the presence of higher holocelluloses content and lower lignin content analyzed. For the clone GG100 the lost mass is the same (32\%) for the temperature ranges of $200^{\circ}, 300^{\circ}$ and $400^{\circ} \mathrm{C}$.

Table 4 presents the mean values of mass and energy productivity estimates. It can be verified that a reflection occurs in the values obtained for the dry mass of the wood in the different clones in relation to the mass of lignin, that in general are result of the values obtained in the IMA. The highest average observed were the GG100 clone, with the end of an energy productivity $11,805 \mathrm{~kW} \mathrm{~h} \mathrm{ha}^{-1}$. The smaller masses, in turn, were obtained by clone AEC0144 presenting

Table 3 - Mass Loss (\%) of different genetic material as a function of temperature ranges.

Tabela 3 - Perda de massa (\%) dos diferentes materiais genéticos em função das faixas de temperatura.

\begin{tabular}{ccccc}
\hline & \multicolumn{4}{c}{ Weight loss $(\%)$} \\
\cline { 2 - 5 } Genetic material & $100^{\circ}-200^{\circ} \mathrm{C}$ & $200^{\circ}-300^{\circ} \mathrm{C}$ & $300^{\circ}-400^{\circ} \mathrm{C}$ & $400^{\circ}-500^{\circ} \mathrm{C}$ \\
\hline GG100 & 1 & 32 & 32 & 9 \\
AEC0144 & 1 & 17 & 47 & 9 \\
AEC0224 & 1 & 27 & 39 & 74 \\
\hline
\end{tabular}

Revista Árvore. 2017;41(5):e410504 
Table 4 - Dry mass estimation of wood, lignin and all available energy.

Tabela 4 - Estimativa de massa seca da madeira, lignina total e energia disponível.

\begin{tabular}{|c|c|c|c|c|c|}
\hline Genetic material & $\begin{array}{c}\text { IMA } \\
\left(\mathrm{m}^{3} \mathrm{ha}^{-1} \mathrm{year}^{-1)}\right)\end{array}$ & $\begin{array}{c}\text { MSM } \\
\text { (t.ha-1 } \text { year }^{-1)}\end{array}$ & $\begin{array}{c}\text { MLT } \\
\left(\text { t.ha }^{-1} \text { year }^{-1} \text { ) }\right.\end{array}$ & $\begin{array}{c}\text { Energy } \\
\left(\mathrm{kW} \cdot \mathrm{hm}^{-3}\right)\end{array}$ & $\begin{array}{c}\text { Energy } \\
\left(\mathrm{kW} \cdot \mathrm{h} \cdot \mathrm{ha}^{-1}\right)\end{array}$ \\
\hline GG100 & 5.88 & 2.18 & 0.67 & 2,008 & 11,805 \\
\hline AEC0144 & 2.41 & 0.82 & 0.23 & 1,828 & 4,405 \\
\hline AEC0224 & 3.69 & 1.27 & 0.40 & 1,831 & 6,755 \\
\hline
\end{tabular}

Where: MSM $=$ dry mass of wood; MLT $=$ total lignin mass.

a low mass of total lignin, reflecting the low value of its dry mass.

\section{DISCUSSION}

Panshin and Zeeuw (1980) argue that during the juvenile phase the basic density suffers a significant increase, followed by a slower growth and when the tree reaches maturity, this property tends to remain more or less constant. The basic density of a wood is an important index among the physical properties, since it influences the others, besides changing the quality of the products derived from this wood. However, it should not be assessed in isolation from other factors that attest to the quality of wood for energy use (Wenzl, 1970; Brazil et al., 1977 cited by Carneiro et al., 2012).

In general, the direct use of wood for power generation from combustion in the form of wood, wood of higher density results in higher energy concentrated fuel, due to the greater mass of fuel contained in the same unit volume (Santos, 2012).

Measuring the amount of heat released from the wood is very important to know the energetic capacity of a given species and is therefore one of the variables used for the selection of species for energetic purposes. It is found that the energy density of the wood is influenced by different factors such as chemical composition, in particular extractives, ash, lignin, as well as moisture that is one of the characteristics that most interferes (Santos, 2010). Pereira (2012) reference average values of the PCS of the main components of wood, cellulose, hemicelluloses and lignin 3.989 Kcal. Kg ${ }^{-1}, 3,206^{-1}$ and 6,006 Kcal.Kg Kcal. $\mathrm{Kg}^{-1}$, respectively. Carneiro et al. (2014) observed that reference was no effect of age for holocelluloses chemical component, among the Eucalyptus clones evaluated in their work. When the objective is energy use, wood with high lignin values is sought because of its contribution to the gravimetric yield in the carbonization process, a fact that is related to its greater resistance to thermal degradation, and in the case of direct wood burning, lignin contributes significantly to the release of energy, since this chemical component, together with some extractives, has less oxygen in its structure than the other components (cellulose and hemicelluloses) (Castro, 2011).

Most volatile content means more time at the stage of flame, this occurs during direct burning of wood, in which gases are released in function of the volatile matter content. In contrast, high fixed carbon content in the wood leads to a slower burning, implying longer residence time of the wood.

Castro (2011) found values for mass loss in juvenile Eucalyptus wood, in the ranges of $100^{\circ}$ to $200^{\circ} \mathrm{C}$, varying in average from $0.4 \%$ to $0.7 \%$ lower values than those found by the present study. Pereira et al. (2013) evaluated the thermal degradation of the juvenile wood of different clones of Eucalyptus by thermogravimetric (TGA/DTG) found in the temperature range of from $100^{\circ}$ to $200^{\circ} \mathrm{C}$ an average weight loss of $0,36 \%$, also low value as found by Castro (2011) and in the present study for the same temperature range.

The authors attribute this minimum value called thermal stability zone of the wood, where the wood components are stable since they are not subjected to long periods of a given temperature ( Raad 2004 cited by Castro, 2011; Pereira et al., 2013).

In the work performed by Pereira et al. (2013), for the temperature range of $250^{\circ}$ to $300^{\circ} \mathrm{C}$, they found a mass loss of $17 \%$, similar to that obtained for clone AEC0144 in the present study, and inferred that the largest part of this lost mass is related to the degradation of hemicelluloses occurring at these temperatures. The highest mass losses were also performed in the temperature ranges of $300^{\circ}$ to $400^{\circ} \mathrm{C}$, with values similar to the one of this study for clones GG100 and AEC0144, with averages of $32 \%$ and $47 \%$, respectively.

Revista Árvore. 2017;41(5):e410504 
In general, the highest degradation peak for the different clones can be attributed to the degradation of holocelluloses, which according to Vidaurre et al., (2011) in juvenile wood have high levels, a fact that was observed in the present work. Lignin degradation peaks were not observed as in the work of Pereira et al., (2013), which can be attributed to its thermal stability, since it undergoes degradation over a wide range of temperatures, only a small fraction decomposes at temperatures below $400^{\circ} \mathrm{C}$. We can observe also a lower mass loss in higher temperatures (Figueroa and Morais, 2009).

The dry mass of the wood obtained by multiplying the average annual increment by the basic density of the wood is fundamental to quantify the production of the stand in dry matter. The density in this case influence this parameter directly, as well as the mass of lignin (Santos, 2012).

Energy productivity is the result of biomass per area, and power quality measured by the calorific value of the wood produced (Santos, 2012). The largest amount of energy in kW.h.ha-1 was presented by GG100 clone with $11,805 \mathrm{~kW} . h . \mathrm{ha}^{-1,}$ which according to Vale et al. (2002) cited by Santos (2012), this energy quantity higher than the other clones is related to the production of mass of dry matter that was higher for said clone.

In Rio Grande do Norte, existing economic activities use firewood extensively in their productive processes as the main source of energy, together with the residential sector. Eucalyptus wood presents great potential as a source of energy due to its characteristics, which can be one of the alternatives to supply the need for wood for energy production in the State, thus replacing traditional species, which are mostly originated from illegal sources.

\section{CONCLUSIONS}

Based on the obtained results it can be concluded that:

1. The clone that excelled in the first year of planting was GG100, with higher energy productivity, followed by clone AEC0224 and AEC0144. The performance of the GG100 clone was due mainly to higher volumetric growth.

2. It should be encouraged deployments species of short rotation in $\mathrm{RN}$ to supply the energy needs of the state.

\section{REFERENCES}

Associação Brasileira de Normas Técnicas ABNT. NBR 8112: carvão vegetal: análise imediata. Rio de Janeiro: 1986.

Associação Brasileira de Normas Técnicas ABNT. NBR 8633: carvão vegetal: determinação do poder calorífico. Rio de Janeiro: 1984.

Carneiro ACO. et al. Qualidade da madeira e tecnologias de produção de carvão vegetal. In: $83^{\text {a }}$ Semana do Fazendeiro. Viçosa, MG: Universidade Federal de Viçosa; 2012.

Carneiro ACO. et al. Potencial energético da madeira de Eucalyptus sp. em função da idade e de diferentes materiais genéticos. Revista Árvore. 2014;38:375-81.

Castro AFNM. Efeito da idade e de materiais genéticos de Eucalyptus sp.na madeira e carvão vegetal [dissertação]. Viçosa, MG: Universidade Federal de Viçosa; 2011.

Cestaro LA, Soares JJ. Variações florística e estrutural e relações fitogeográficas de um fragmento de floresta decídua no Rio Grande do Norte, Brasil. Acta Botanica Brasilica. 2004;18:203-8.

Figueroa MJM, Moraes PD. Comportamento da madeira a temperaturas elevadas. Ambiente Construído. 2009;9(4):157-74.

Goldschimid O. Ultraviolet spectra. In: Sarkanen KV, Ludwig CH. Lignins: occurrence, formation, structure and reactions. New York: J. Wiley; 1971. p.241-66.

Gomide JL, Demuner BJ. Determinação do teor de lignina em material lenhoso: método Klason modificado. O Papel. 1986;47(8):36-8.

Mora AL, Garcia CH. A cultura do eucalipto no Brasil. São Paulo: Universidade Federal de Viçosa; 2000.

Nogueira LAH. et al. Dendroenergia: Fundamentos e aplicações. Brasília: ANEEL; 2000.

Paludo G, Borges AJ, Gonçalves TS. Produção e rentabilidade de florestas plantadas do gênero eucalipto. In: Resumos do $2^{\circ}$ Congresso Brasileiro

Revista Árvore. 2017;41(5):e410504 
de Eucalipto. São Paulo: 2013. p.4.

Panshin AJ, De Zeeuw C. Textbook of wood technology. $4^{\text {th }}$. ed. New York: 1980.

Pareyn F, et al. Cuidando da Caatinga. Associação de Plantas do Nordeste (APNE) \& Royal Botanic Gardens, KEW, 2013.

Pereira BLC. Qualidade da madeira de Eucalyptus para a produção de carvão vegetal [dissertação]. Viçosa, MG: Universidade de Viçosa; 2012.

Pereira BLC. et al. Estudo da degradação térmica da madeira de Eucalyptus através de termogravimetria e calorimetria. Revista Árvore. 2013;37:567-76.

Santos RC. Parâmetros de qualidade da madeira e do carvão vegetal de clones de eucalipto [tese] Lavras: Universidade Federal de Lavras, 2010.

Santos LC. et al. Propriedades da madeira e estimativas de massa, carbono e energia de clones de Eucalyptus plantados em diferentes locais. Revista Árvore. 2012;36:971-80.

Silva DA. et al. Ponto de amostragem ao longo do fuste para estimativa do poder calorífico da madeira. Ciência Rural. 2012;42(9):1588-95.

Tappi Technical Divisions And

Committees. TAPPI test methods. Atlanta: 1998.

Trugilho PF, Lima JT, Mendes LM. Influência da idade nas características físico-químicas e anatômicas da madeira de Eucalyptus saligna. Cerne. 1996;2:94-111.

Vidaurre GB et al. Lenho juvenil e adulto e as propriedades da madeira. Floresta e Ambiente. 2011;18:469-80.

Vital BR. Métodos de determinação de densidade da madeira. Viçosa, MG: SIF, 1984. (Boletim técnico, 1). 